\title{
Internal Migration in Germany, 1995-2010: New Insights into East-West Migration and Re-urbanisation
}

\author{
Nikola Sander
}

\begin{abstract}
Over the last two decades, patterns of internal migration in Germany have been discussed under the headings of East-West movements and sub-and re-urbanisation. This paper argues that the intense scientific and public debate that ignited about the possible causes and consequences of internal migration should be based on a clear understanding of how internal migration flows impact on regional population change. Using the German Internal Migration (GIM) database, a unique new dataset that holds annual interregional migration counts drawn from the population register for 397 regions with temporally consistent boundaries, this paper aims to provide a more comprehensive picture of the spatial structure of inter-county migration in Germany and how it has changed over the period 19952010. To reduce the complexity of the county-level flow data and to facilitate the identification of patterns and trends, county-to-county flows were analysed using a spatial framework of 132 "analytical regions". The results show that the intensity of migration between East German regions has been higher than East-West migration throughout the period, suggesting that the former type of migration has a stronger impact on rural population decline than commonly believed in the literature. Following a strong suburbanisation pattern in the 1990s, over the last decade, migration between counties in eastern Germany has resulted in a growing concentration of population in the cities of Berlin, Leipzig and Dresden. Increasing net migration gains were recorded by many urban cores across Germany. The trend was driven by both continuing in-migration of young adults in search for education and employment, and by a cessation of the long-term trend of family out-migration to the cities' suburban and non-metropolitan hinterlands.
\end{abstract}

Keywords: Internal migration · East-West · Reurbanisation · Regional population change $\cdot$ Germany

\footnotetext{
This article has coloured figures and data in an online Appendix: DOI 10.12765/CPoS-201405en, URL: http://www.comparativepopulationstudies.de/index.php/CPoS/article/view/89/175.
} 


\section{Introduction}

Over the last two decades, two seemingly substantial shifts in the patterns of internal migration ignited an intense scientific and public debate about the possible causes and consequences of regional population change: East-West migration and reurbanisation. Such a debate is extremely timely, especially in the context of low birth rates, increasing life expectancy and comparatively low levels of international migration. As very few predominantly urban counties record a natural increase of population (Gatzweiler/Schlömer 2008), the movement of people between Germany's regions plays a key role in shaping population growth and age structures.

Following reunification in 1990, rapid deindustrialisation, labour market restructuring and subsidised housing investment caused a tidal wave of internal migrants leaving the East German cities for the countryside. However, the fact that the total volume of moves to suburban areas was considerably larger than out-movement to western German states has not been reflected in the literature. In the 1990s, studies focused primarily on aggregate intensities of East-West migration between the six states (Länder) in eastern Germany (including Berlin) and the ten states in western Germany (Heiland 2004; Kontuly et al. 1997). The literature points to strong impacts of this type of movements on regional population growth in the years following reunification. Net losses from eastern states were highest in the years 1989/90, with a second peak in the temporal trend visible in 2001 (Heiland 2004). Out-migration was found to be highest among young adults with above average education, who left non-metropolitan regions in the East and moved to western states with good job prospects (Heiland 2004; Kontuly et al. 1997; Kröhnert/Vollmer 2012; Peukert/ Smolny 2011). Thus, to borrow the words of Kontuly et al. (1997: 43): "the overall consequence of unification [...] was a broad spatial distribution of growth to all Western German regions and a wide pattern of loss in the East".

Much less attention has been devoted to the patterns and trends of migration between regions in eastern Germany and their impact on population decline, with the exception of Sch/ömer (2009). This is despite the fact that migration propensities decrease with distance, so that the volume of short-distance movements is much higher than that of longer distance moves to a different state (Lee 1966). Thus, intra- and interregional migration, especially between the larger cities, their hinterlands and non-metropolitan areas can be expected to have a much stronger impact on regional population change than longer distance moves. Although not in the context of East-West migration, Kabisch et al. (2010) find that the recent growth of East German cities is primarily driven by changes in the propensities of movement between the larger cities and their non-metropolitan hinterlands.

Since the beginning of the century, a new wave of migrants appears to be directed towards the city centres, a phenomenon which has been speculated about and discussed quite extensively under the headings of reurbanisation and renaissance of the city (see, for example, Hesse 2008; Köppen 2008; Siedentop 2008). Studies focused on specific perspectives (for example, the concept of the city as a place) and aspects (for example, individual level decision making, values and preferences) of residential mobility and internal migration (see, for example, Haase et 
al. 2010; West et al. 2008). There is a general consensus that urban areas in several European countries have been growing since the late 1990s, and that migration is a key driver of this growth (Buzar et al. 2007; Colomb 2007). These conclusions were drawn mainly from case studies of European cities, which were characterised by a geographical focus on eastern Germany and the UK (Kabisch et al. 2010; Rink et al. 2012).

Given the distinctive history of eastern Germany, the findings may be limited in their general applicability. But more comprehensive studies of nation-wide patterns of interregional migration and changes over time have been hindered by the lack of adequate data. While the national population register data are ideally suited for the study of migration flows at the county level, changes over time in the geography for which the data are collected impede any time series analysis. As a consequence, more recent work on the characteristics of internal migrants has made use of the German Socio-Economic Panel (Kemper 2008; Peukert/Smolny 2011). While these longitudinal survey data allow key insights into the determinants of migration and the migration-triggering effects of live course events, the sample size inevitably restricts the level of spatial detail that is essential for analysing migration spatial structure.

This paper overcomes the problem of non-comparability of inter-county migration flow data due to changing spatial boundaries. The new German Internal Migration (GIM) database holds information on migrant flows between 397 counties (Kreise) with consistent boundaries, covering the period 1995 to 2010 . Such harmonised inter-county migration flow tables allow new insights into trends and patterns of internal migration in Germany. In considering the debate about East-West migration and reurbanisation as key drivers of regional population change, five key questions emerge that will help determine whether the evidence drawn from case studies and aggregate analyses hold at a county scale: Has the intensity of East-West migration been higher or lower compared to other types of moves? Have non-metropolitan areas been the primary regions of origin of East-to-West migration flows? How have the spatial patterns and intensities of inter-county migration changed over time, and did they differ by age? Has the recent trend of renewed urban growth been universal across Germany? Which migration flows can be identified as the drivers of this trend?

The paper continues with a description of the harmonised migration flow data and the spatial framework, followed by an analysis of the intensity of migration by type of move. The paper then turns to introduce bicomponent mapping as a mapping technique for visualising changes over time in the spatial patterns of migration, and then proceeds to evaluate separately the dynamics in the spatial patterns of the three most mobile age groups. This is followed by a discussion of the key regions of origin and destination of migrants to and from the largest German cities. The paper ends with a discussion of the findings in the context of population ageing and the growing attractiveness of the city cores as a place to live. 


\section{Data}

The analysis presented in this paper uses data on changes in place of residence as captured by the German population register. The data were kindly provided by the German Federal Statistical Office (Destatis). Population registers record every change of permanent residence across municipal boundaries as an event and thus capture all moves within a 1-year period, including multiple and return moves. There might be some undercount of young adults who move several times after leaving the parental home before registering. The data are disaggregated by six age groups and cover the period 1995 to 2010.

The data provided by Destatis contain movement events data on place-to-place migration flows between German counties (Kreise). Numerous boundary changes that occurred at the county level since 1995 generate significant spatial discontinuities. Hence, comparisons of migration patterns and intensities across counties and over time require the development of a temporally consistent, customised geography. The German Internal Migration (GIM) database developed by the author is based on such a temporally consistent geography of Temporally Consistent Counties (TCCs), and thus overcomes the problem of temporal incomparability. The customised geography was developed by adopting the "Update to contemporary zones" approach discussed in Blake et al. (2000). This approach appeared to be most appropriate given that most historic boundary changes involved the aggregation of several smaller counties to one larger region. The number of counties in Germany decreased from 444 in 1995 to 412 in 2010. In the harmonisation process, the most recent county geography for the year 2010 was used as the benchmark and migration flow data from earlier years were translated to the 2010 zonal system. The translation was based on a concordance list that sets out all original county IDs, the Temporally Consistent County (TCC) IDs and the type of boundary change (see Supplementary Online Material). Information about boundary changes obtained from German state governments and the Gemeindeverzeichnis-Informationssystem. ${ }^{1}$ The concordance list sets out the links between the original (unharmonised) geographies and the harmonised zonal system that is based on the 2010 county geography.

Based on the information given in the concordance list, all of the earlier geographies were converted to larger regions. In Brandenburg, Saxony-Anhalt and Thüringen, counties were split and the resulting parts merged with different counties. In such cases, all counties affected by the split were merged to form new, larger regions. Consequently, the TCC geography consists of 397 regions, whereas the 2010 county geography that was used as the benchmark contains 412 regions. An example for such a split up is Anhalt-Zerbst, a county in Saxony-Anhalt that was split into three parts during the reforms in 2007. All three counties that gained parts of Anhalt-Zerbst (i.e. Jerichower Land, Wittenberg and Anhalt-Bitterfeld) thus had

1 https://www.destatis.de/DE/ZahlenFakten/LaenderRegionen/Regionales/Gemeindeverzeichnis/NamensGrenzAenderung/NamensGrenzAenderung.html (Accessed on 01.09.2012) 
to be converted into one larger region. Migration data for the years 1995 to 2010 were then aggregated to the harmonised, larger zones for subsequent analysis.

In addition to the harmonisation of the zonal system, the migration counts held by the GIM database were corrected for flows that were unusually large in volume due to resettlement of ethnic German migrants (Spätaussiedler) from eastern European countries and asylum seekers. All ethnic Germans and their families returning to Germany are required to register with a small number of so-called "border transit centres" (Grenzdurchgangslager), where the legal process is initialised so that the returning migrants can become naturalised German citizens. Following naturalisation, returning migrants and their families are then assigned to smaller institutions across Germany based on where places are available at the time. The initial flows to the border transit centres are recorded as international moves, whereas the latter flows to regional institutions are recoded as internal moves, introducing substantial bias into the official statistics on internal migration.

The intensities, patterns and reasons for such resettlement have been discussed in detail by Sch/ömer (2012). The flow data held by the GIM database were adjusted for flows from and to the following eight counties: Göttingen (denoted as "TCC ID" 21 in the Supplementary Online Material), Plön (10), Osnabrück (49), Dortmund (107), Unna (117), Rastatt (196), Freudenstadt (204), and Ostprignitz-Ruppin (337). As noted by Sch/ömer (2012), the adjustment is not straightforward since the timing and intensity of the resettlement of Spätaussiedler differs substantially across counties. Therefore, all potentially inflated migration flows were set to missing and then re-estimated.

Missing data methods commonly used for the indirect estimation of migration flows, such as iterative proportional fitting (IPF) or log-linear models (see, for example, Rogers et al. 2010), require the margins of a flow table (i.e. total in-migration and out-migration for each region) to be known. In case of the German flow data, however, these totals are potentially inflated by the resettlement practices. Spatial interaction models offer a practical alternative in situations where the margins for some regions are unknown and the number of missing cells in the flow table is small. In the GIM database, 6280 (or 4 percent) of a total of 157212 county-to-county flows were estimated using spatial interaction models. To summarise, the model assumes that the size of a migration flow between counties is proportional to the population size of the origin and destination and the distance between the two counties (Boy/e 1995; Flowerdew/Lovett 1988). The unconstrained spatial interaction model based on the Poisson distribution has the form (see Boyle 1995):

$$
M_{i j}=\exp \left(\beta_{0}+\beta_{1} \ln P_{i}+\beta_{2} \ln P_{j}+\beta_{3} \ln d_{i j}+\beta_{4} C_{i j}\right)+\varepsilon_{i}
$$

where $M_{i j}$ is the predicted count of movement events between counties $i$ and $j . P_{i}$ and $P_{i}$, denote the size of populations in origin $\left(P\right.$, and destination county $\left(P_{j}\right)$. The distance in kilometres between county centroids is denoted by $d_{i j}$ and $C_{i j}$ is a contiguity variable that controls for movements between neighbouring counties. $\varepsilon_{i}$ is the error term. Table 1 sets out exemplary results from the Poisson models for 389 counties in 1995 and 2010 that were used to estimated missing cells. Separate mod- 
Tab. 1: $\quad$ Results for spatial interaction models used to estimate flows affected by the redistribution of ethnic Germans and refugees

\begin{tabular}{lrrrr}
\hline & \multicolumn{2}{c}{1995} & \multicolumn{2}{c}{2010} \\
Variable & Coefficient & $\begin{array}{c}\text { Standard } \\
\text { error }\end{array}$ & Coefficient & $\begin{array}{c}\text { Standard } \\
\text { error }\end{array}$ \\
\hline In(Origin population) & 0.990 & 0.001 & 0.904 & 0.001 \\
In(Destination population) & 0.757 & 0.001 & 0.974 & 0.001 \\
In(Distance in km) & -1.199 & 0.002 & -1.300 & 0.001 \\
Contiguity & 1.393 & 0.001 & 1.081 & 0.002 \\
Constant & -12.747 & 0.014 & -13.890 & 0.015 \\
Deviance & $1,928,269$ & & $1,866,213$ & \\
No. of observations & 150,932 & & 150,932 & \\
Residual df & 150,927 & & 150,927 & \\
McFadden's Adj R-squared & 0.81 & & 0.81 & \\
\hline
\end{tabular}

Source: Author's calculations based on Destatis data

els were run for each age group and year, with estimated model parameters being broadly similar across age groups and time. The models were run for migrant flows between $389(=397-8)$ regions to ensure that the results were not influenced by the resettlement of Spätaussiedler.

As expected from the literature, the distance-decay effect on inter-county migration was negative for both years, indicating that the size of migrant flows decreased with the distance moved. This tendency is also reflected in the contiguity variable being strongly positive. The effects of population size at the origin and destination were also strongly positive in both years. The adjusted R-squared values indicate that the models explain more than 80 percent of the variance in the migration flows, suggesting that the approach is well-suited for estimating missing cells. Figure 1 compares the observed and estimated in-migration and out-migration flows for the eight counties affected by resettlement.

The resulting large interaction database holds migration counts for 16 annual intervals for 397 origins, 397 destinations, two sexes and six age groups (see the Supplementary Online Material for a list of all 397 TCCs and their corresponding unharmonised [original] counties). The flow tables between the TCCs for the period 1995-2010 are also provided in the Supplementary Online Material. The complete set of flow tables disaggregated by age groups and gender can be obtained by contacting the author. 
Fig. 1: Observed and estimated total in-migration and out-migration for eight counties affected by resettlement of Spätaussiedler and asylum seekers

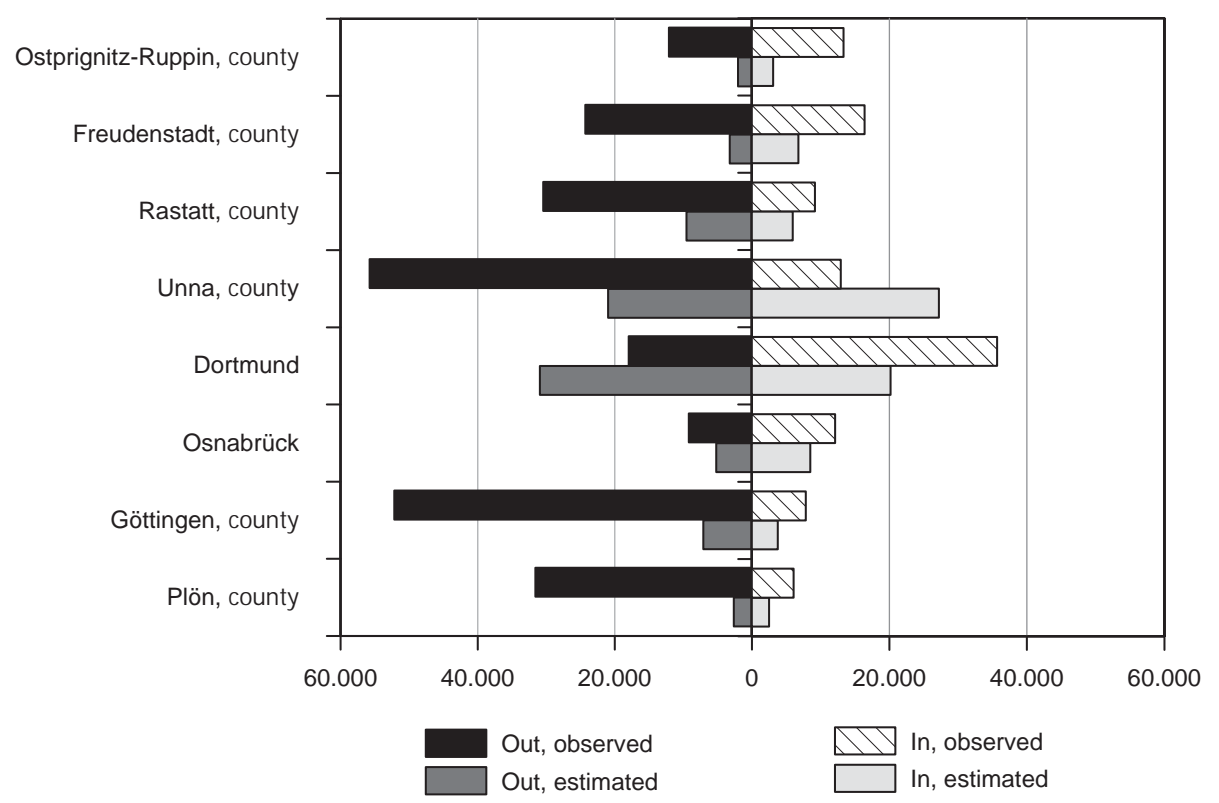

Source: Author's calculations based on Destatis data

\section{Spatial framework}

The GIM database holds migration counts for two temporally consistent spatial frameworks to facilitate the analysis of inter-county migration in Germany over the period 1995 to 2010: one for "Temporally Consistent Counties" (TCCs) and one for "Analytical Regions" (ARs). The TCC geography is similar to the 2010 county geography used in official statistics; the only difference being that five eastern German counties were aggregated to larger regions to ensure temporal consistency. The AR geography, which was developed to facilitate analyses of migration patterns and trends by type of move is used in this paper.

The AR geography is used as this paper focuses on East-West migration and on trends in the spatial patterns of migration that may indicate reurbanisation tendencies. The spatial framework of analytical regions is based on a single county or aggregations thereof and was originally developed by the Federal Institute for Research on Building, Urban Affairs and Spatial Development (BBSR 2009). The aim of its design was to provide a manageable set of regions that enables flows to and from different types of regions to be distinguished. However, the Modifiable Areal Unit Problem, which impacts on the observed intensity of migration (Openshaw 1984), cannot be fully avoided since the spatial framework is determined by the administrative regions that are used for data collection. The BBSR typology classifies counties into three main groups (agglomeration regions, urbanised regions and 
Fig. 2: $\quad$ Spatial framework for the study of internal migration for 132 analytical regions, typology adapted from BBSR

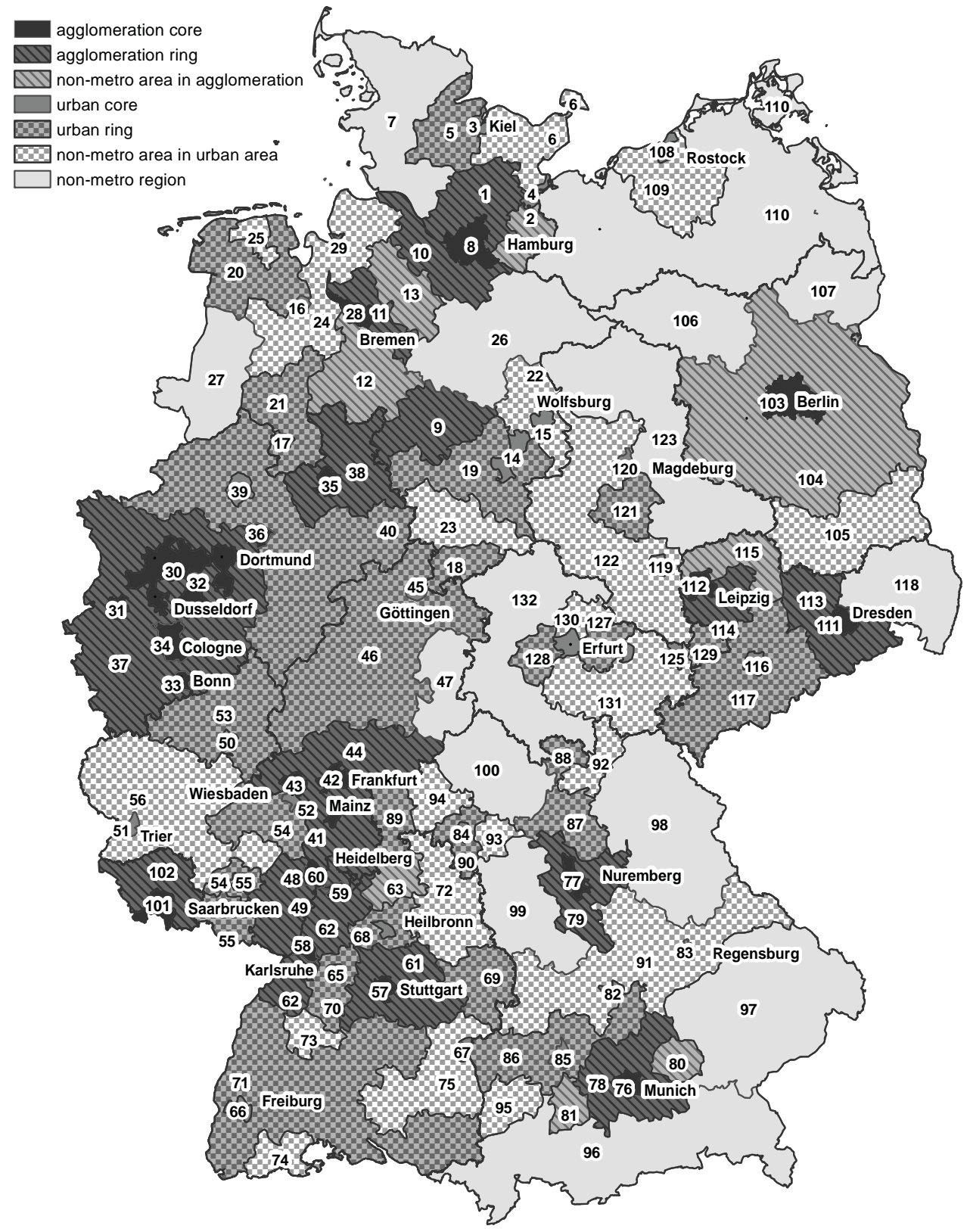

Source: own design 
non-metropolitan regions), and within these groups distinguishes the cores from their high-density ring and their lower-density extended hinterlands.

For the development of the spatial framework used in this paper, high-density and lower-density hinterlands were aggregated so that seven region types remained: agglomeration core, agglomeration ring, non-metro area in agglomeration, urban core, urban ring and non-metropolitan areas. As shown in Figure 2, all neighbouring counties of the same type and within the same state (Bundesland) were aggregated to form contiguous regions, whereas the cores remained as separate regions. In summary, the 132 Analytical Regions fall into seven types of regions: 23 agglomeration core regions, which are the large cities with substantial higher-order functions and strong linkages with other urban centres; 15 agglomeration ring regions, which are the surrounding or adjacent counties that have a close functional relationship with the core; 8 non-metro areas in agglomerations, which tend to be more distant from the core but in some cases may also be surrounding the core; 27 urban cores, which are the medium to large cities with fewer higher-order functions than the agglomeration cores; 23 urban ring regions, which have functional links with the urban cores but vary in the strength of such links; 21 non-metro areas in urban areas, which are essentially less densely populated hinterlands of urban areas; and 15 non-metro regions which are the least-densely populated parts of the country with the weakest functional links to core regions. All TCCs and the corresponding analytical regions are listed in the Supplementary Online Material.

The distinction between agglomeration ring and non-metro area in agglomeration is partly based on the population density of the counties, which in turn is influenced by the area size of the counties. This issue is of particular importance for the city of Berlin and its hinterland. Berlin is a single county, but there are spill-over effects into neighbouring counties. These counties are large in size and characterised by relatively low population density. Thus, in the spatial framework used in this paper, no county is classified as Berlin's agglomeration ring. Overall, the distinction between cities and their hinterlands is somewhat blurred due to spill over effects of the city core into neighbouring regions as well as commuting ranges that might not encompass the entire region that is classed as "agglomeration ring".

\section{$4 \quad$ Intensity of internal migration}

The scholarly literature is characterised by a strong focus on trends in the intensity of East-West migration since reunification. While the overall volume of flows from eastern to western German regions has been substantial in the early 1990s, its intensity and, consequently, its impact on the population growth in the regions of origin have declined relative to other types of movements since the mid-1990s. The migration rates shown in Figure 3 highlight substantial differences in migration intensities by type of move, which are stronger than changes in migration over time. Since the number of migration events recorded over an annual period is directly related to the size of the corresponding population at risk of moving, the occurrence-exposure rates shown in Figure 3 were calculated by expressing the migra- 
Fig. 3: Migration rates (as percent of mid-year population) for moves between and within West and East Germany (including Berlin)

Migration intensity in \%

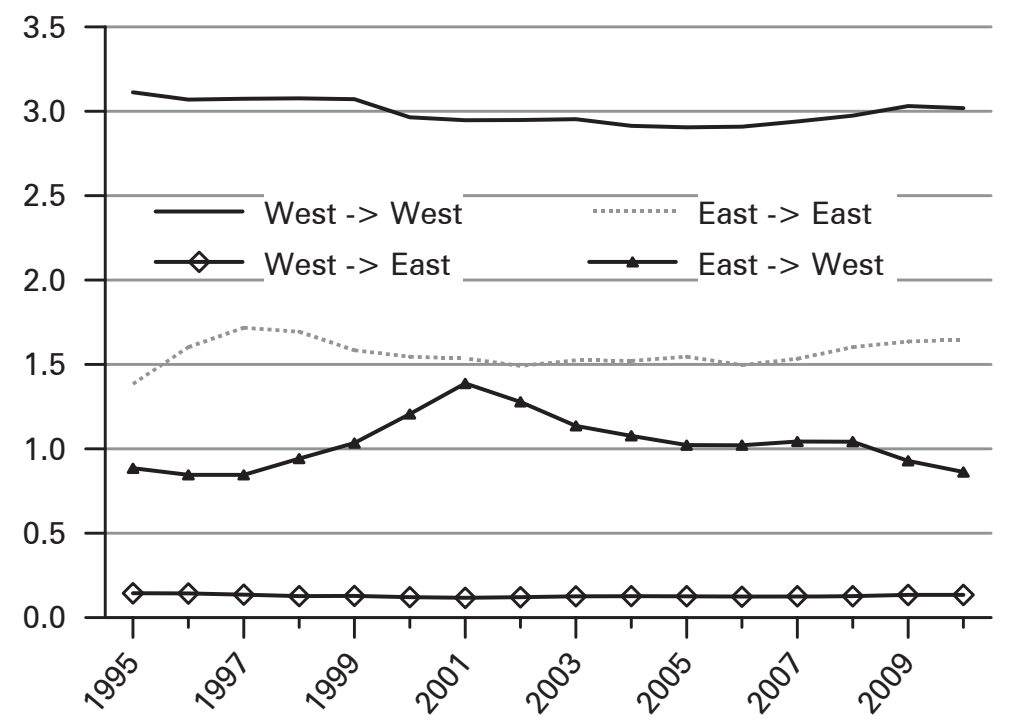

Source: Author's calculations based on Destatis data

tion count in a given year as a percentage of the mid-year population in the origin region. As expected, west-to-east movement was lower than the counter-flow to western regions, which peaked in the year 2001. However, migration between counties in eastern Germany was higher in intensity than migration from eastern to western counties across the entire period.

One may argue that the considerably higher intensity of east-to-east migration compared to east-to-west migration is primarily due to movements to and from Berlin. Figure 4 reveals that this is not the case. The number of migrations between all eastern counties excluding Berlin was highest in 1997, which reflects the suburbanisation trend of the 1990s. The number of movements from eastern (excluding Berlin) to western counties peaked sharply in 2001, but was lower than east-toeast movements throughout the entire period. In contrast, movements to and from Berlin were much more stable over time, with marginal differences in intensities between inbound and outbound moves.

High intensities of migration do not necessarily imply a strong impact of migration on population redistribution. A common assumption is that it was East-West migration that had the strongest impact on population decline in East German regions. In other words, East German counties would have recorded stronger net losses to counties in the West compared with net losses to other East German counties. Figure 5 depicts in each year, 1995-2010, the number of Temporally Consistent Counties with net loss (left hand figure) and with net gain (right hand figure). Both figures show separately the net gain or loss with West German and with East Ger- 
Fig. 4: Number of migrations for moves between and within East Germany (excluding Berlin), West Germany and Berlin

Total number of migrations, in thousands, moves within the West not shown

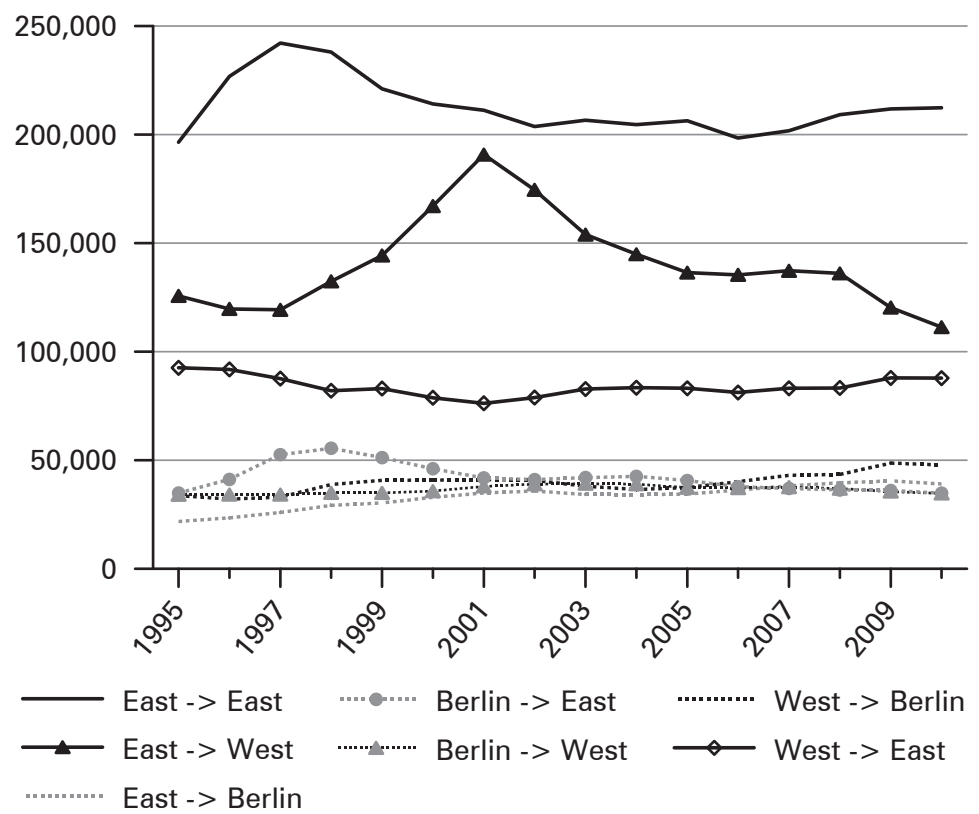

Source: Author's calculations based on Destatis data

Fig. 5: Net migration gains and losses in East German TCCs disaggregated by East and West, 1995-2010

TCCs with net loss

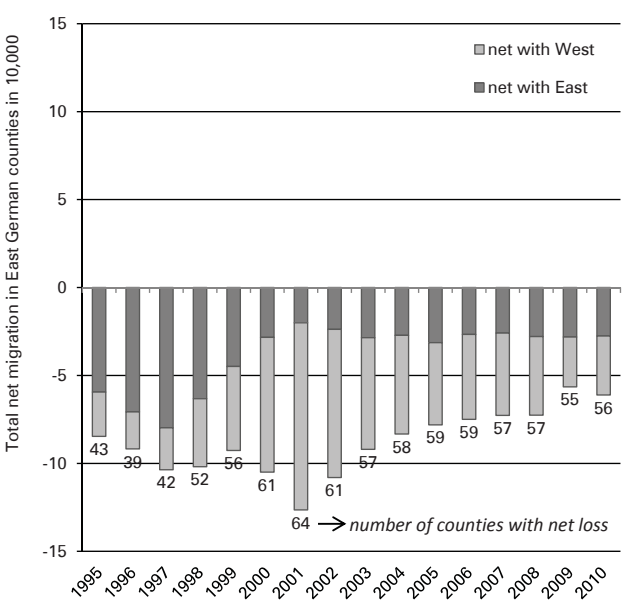

TCCs with net gains

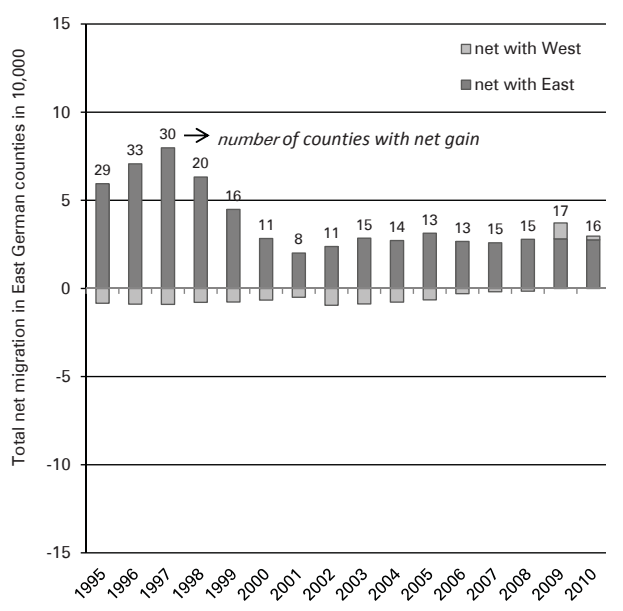

Source: Author's calculations based on Destatis data 
man counties. Labels indicate the number of counties with net loss (left hand figure) and net gain (right hand figure). It appears that East-West migration had a stronger impact on population decline in eastern counties than movements to other counties in the East in the period from 1999 to 2008. However, the degree of the impact declined substantially in recent years. In 2010, half of all net losses from East German counties were to other counties in the East. Moreover, counties in the East with overall net gains have begun to record a positive net balance with counties in West Germany in recent years. It is worth noting that the East German counties recording net gains changed over the 16 year period. In the late 1990s, it were the city hinterlands that recorded strong net gains from the core centres, while the cores regained their attractiveness as destinations and showed a net migrant gain since the turn of the century.

The net migration rates calculated by region type also reflect the two migration patterns that have dominated the literature. Figure 6 demonstrates that the suburbanisation pattern observed in East Germany in the 1990s resulted in strong net losses of the urban cores and, although to a lesser degree, of the agglomeration

Fig. 6: Net migration rates among the total population (as percent of mid-year population) for inter-county flows aggregated by region type for the whole of Germany

Net-migration rate (\%)

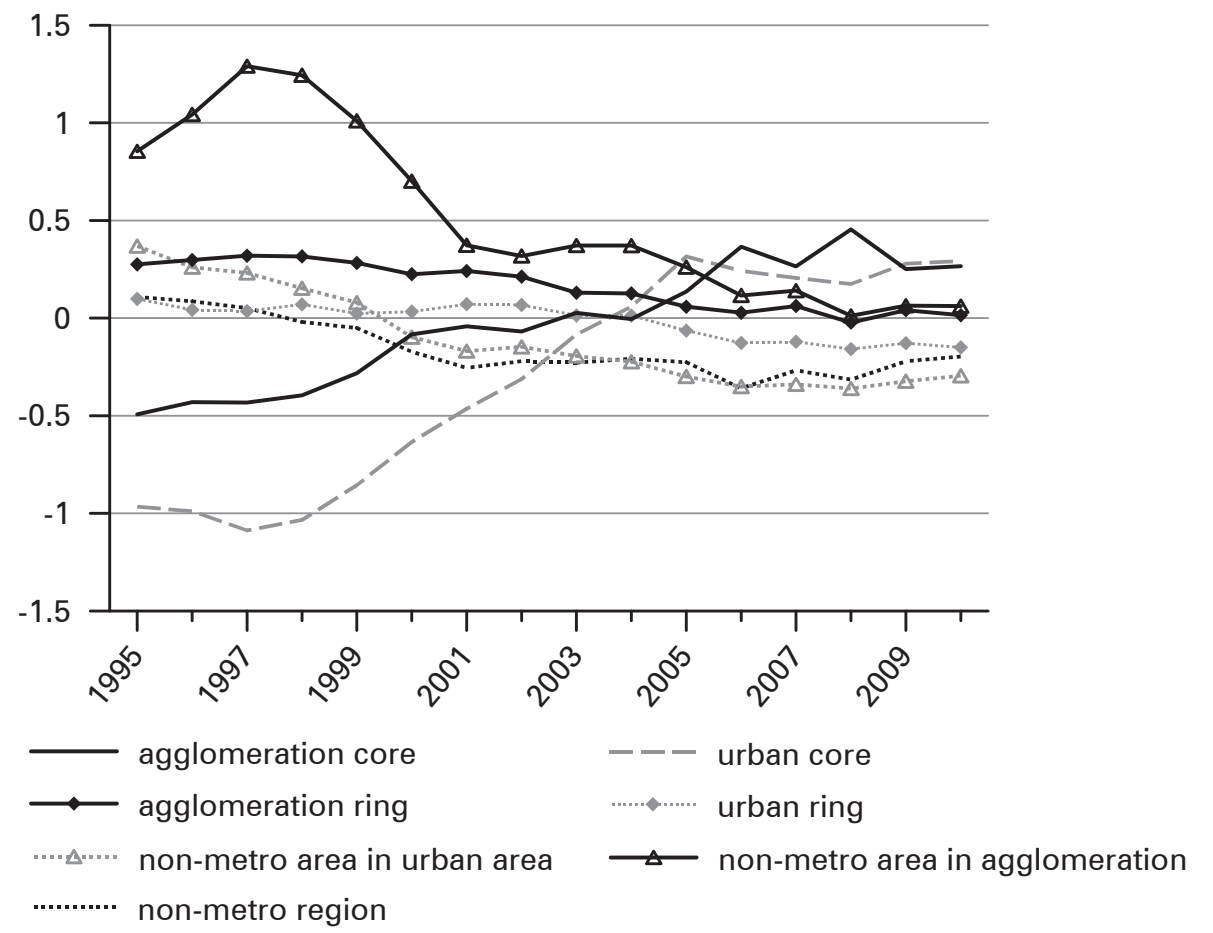

Source: Author's calculations based on Destatis data 
cores. The primary destination of this movement pattern was the agglomeration hinterland with the ring and the non-metropolitan areas in agglomeration regions. At the beginning of the century, the overall intensity of migration decreased and net gains and losses converged to zero. Over recent years, the pattern of net gains and losses has changed fundamentally, although the levels of net migration remained lower than they were in the mid-1990s.

The propensity to migrate varies systematically not only by type of move but also by age. Such regularities in the age pattern are commonly described as being consistent across countries and over time (Rogers et al. 1978). The age-specific migration rates for all inter-county moves closely resemble those found in other western societies (not shown). It is remarkable, however, that the age at which the profile peaks has shifted leftwards over time. This shift has been paralleled by a substantial increase over time in net migration of 18-24 year olds to the agglomeration and urban cores as shown in Figure 7. At the same time, non-metropolitan regions and the core hinterlands recorded increasing net losses of young adults. The core regions are becoming more attractive for both young adults in search of

Fig. 7: Net migration rates among 18-24 year olds (as percent of midyear population in the respective age group) for inter-county flows aggregated by region type for the whole of Germany

Net-migration rate of $18-24$ year olds $(\%)$

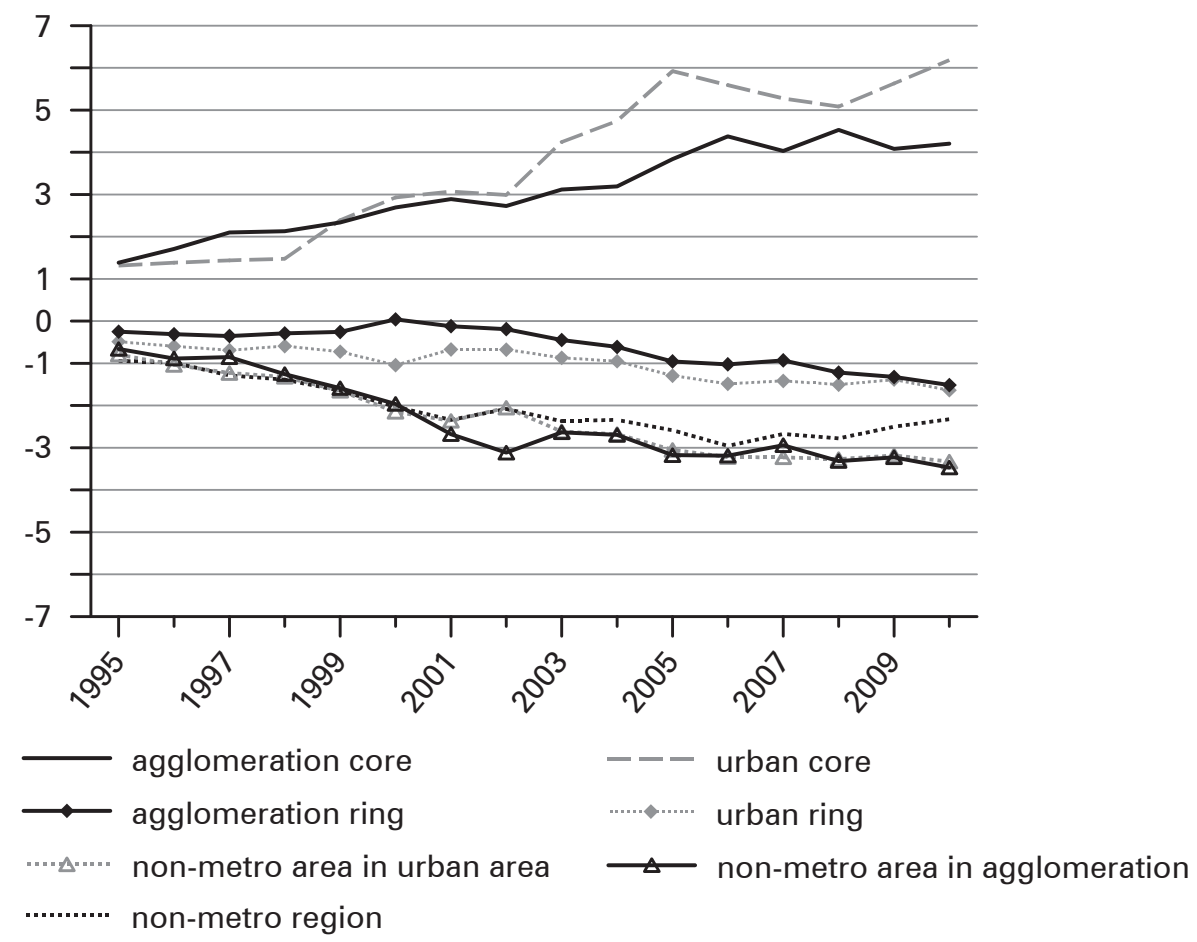

Source: Author's calculations based on Destatis data 
job opportunities and tertiary education, and for middle-aged (30-49 years) people who want to balance jobs and family life. Until the turn of the century, people aged 30-49 tended to move from the cores to their hinterlands and to non-metropolitan areas, which were regarded as better places to raise a family. Figure 8 shows that this pattern has changed substantially over the last 16 years, with more and more people aged 30-49 opting to stay in the city rather than moving to the hinterlands.

Fig. 8: Net migration rates among 30-49 year olds (as percent of midyear population in the respective age group) for inter-county flows aggregated by region type for the whole of Germany

Net-migration rate of $30-49$ year olds (\%)

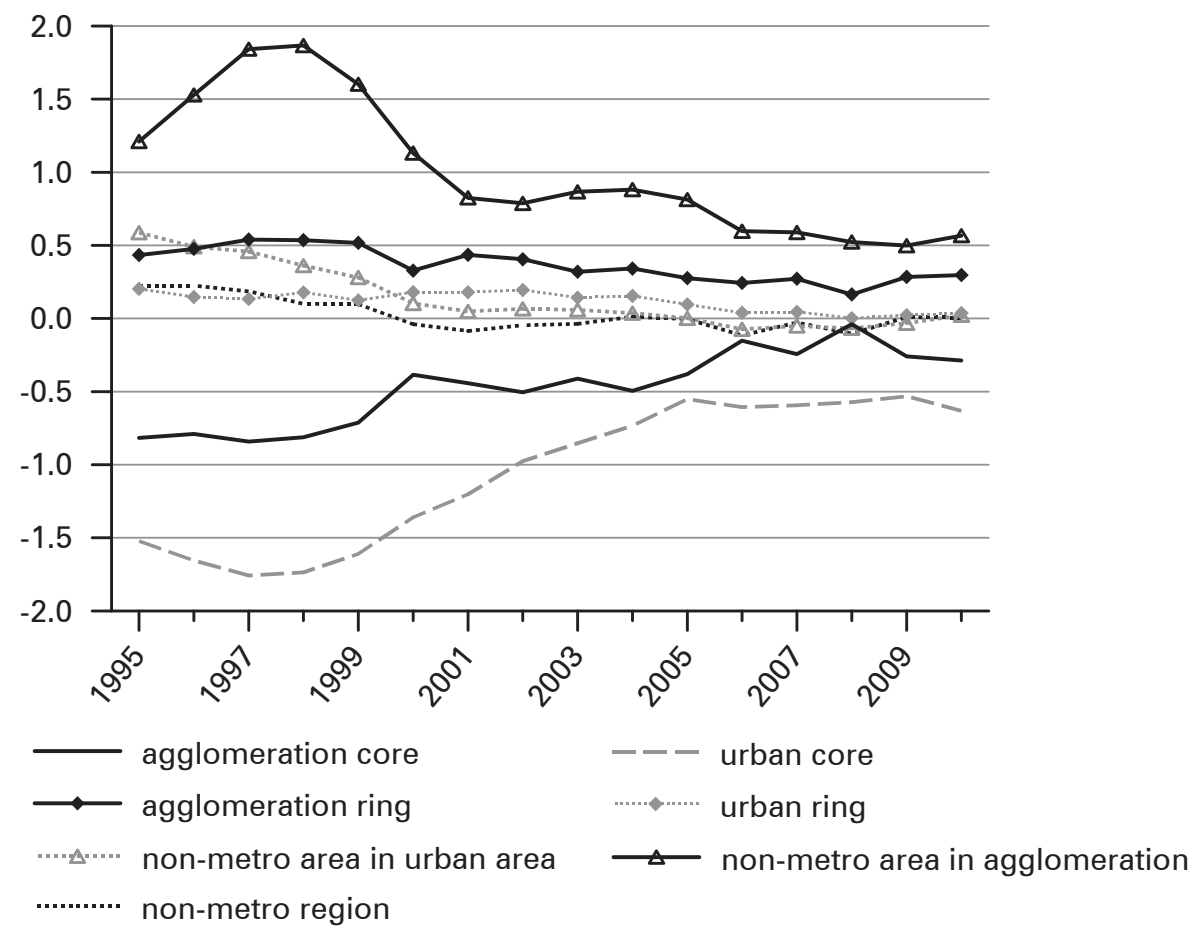

Source: Author's calculations based on Destatis data

\section{$5 \quad$ Bicomponent trend mapping}

Conventional approaches to the visualisation of regional population change use a series of maps to separately display the intensity and change over time, making it hard to identify trends. In order to more effectively visualise temporal trends in spatial patterns of internal migration, bicomponent mapping translates the three dimensions of intensity, space and time into a two-dimensional map (for an application to regional population growth in the USA, see Schroeder 2009). Net-migration 
rates for ARs for the period 1995-2010 are used to illustrate the method. In a first step, principal component analysis (PCA) of net migration rates for the 132 ARs and for each year, 1995-2010, is used to identify the first two components. In other words, PCA was run with 132 regions and 16 net rates (132 x 16 data entries). Figure 9 depicts the loadings of the first two components for each year. The first component explains 47 percent of the variance in net-migration rates and indicates the overall level of net-migration across the 16 -year period. The second component explains 31 percent of the variance and captures the change over time in net-migration (i.e. increasing or decreasing). This interpretation of the components with regards to overall level and change over time is also valid for the analysis of net-migration for specific age groups presented in Section 6.

Fig. 9: Component loadings, PCA of net-migration rates at AR level, 1995-2010

Component loading

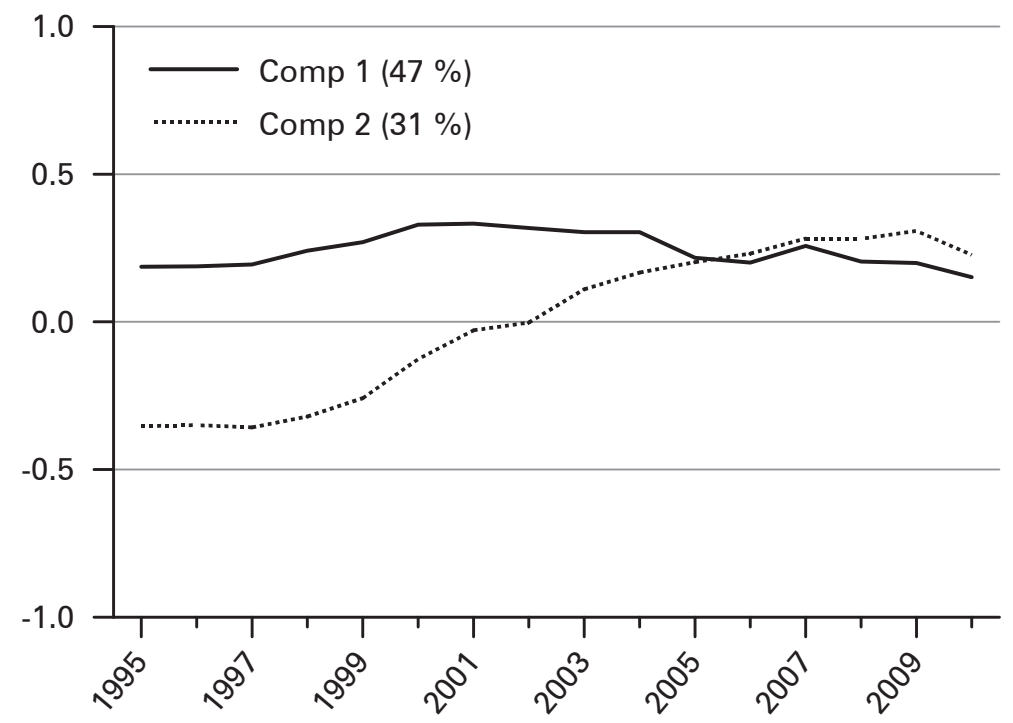

Source: Author's calculations based on Destatis data

In a second step, the region-specific loading scores for the first and second component are each divided into three quantiles, resulting in nine possible combinations of groups of analytical regions. In a third step, a three-by-three matrix of mean trends is constructed, based on the intersections of each pairing of PC 1 (overall level) and PC 2 (change over time) quantiles. The matrix shown in Figure 10 has nine fields, which are indicated by Roman numerals and arranged based on the regions' component loading scores. The mean levels and changes over time in net-migration are shown in each field. These are net-migration rates in percent, rather than regions' component scores. The field in the bottom left corner shows the mean trend in net-migration for 21 regions ( $n$ : 21), where the intensity of net migration was low and declined even further over time. At the other end of the spectrum, the top-right 


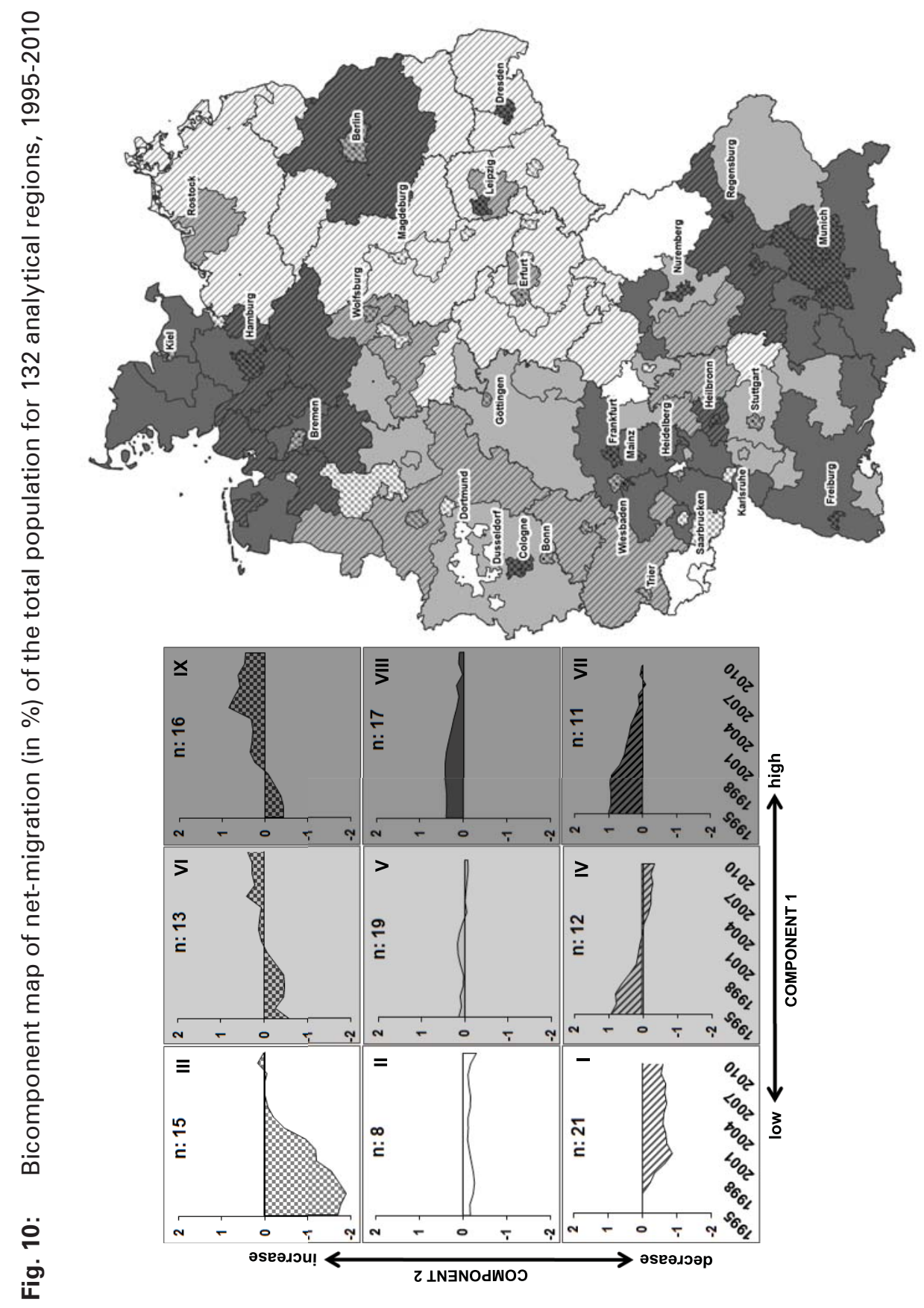

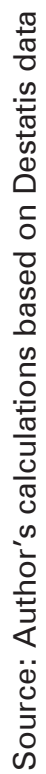


field indicates a high intensity and increasing trend for 16 regions. The bicomponent trend matrix is accompanied by a map that indicates the group membership of analytic regions.

\section{Spatial patterns of internal migration}

\subsection{Dynamics among the total population}

Not only the intensities, but also the destination choices among migrants changed substantially over the last two decades. As expected from the literature review, the overall trend was towards strong net gains in the core regions and decreasing gains or even losses across all non-core regions. This pattern reflects the revival of the residential function of the cities that follows the longer-term suburbanisation pattern. The bicomponent matrix in Figure 10 depicts systematic variations in trends and intensities across the 132 analytical regions. Net migration increased in 44 regions (fields III, VI and IX), decreased in 61 regions (fields I, IV, VII and VIII) and remained stable in 27 regions (fields II and $V$ ). No regions had strong net gains across the entire period.

Changes over time were stronger in northern Germany, with the cities of Bremen, Kiel, Wolfsburg, Göttingen, Berlin and Rostock experiencing a marked recovery, while their hinterlands changed from being strong net receivers of migrants to net senders. These dynamics were somewhat less pronounced in south-eastern and western regions. The only non-core regions that experienced a positive trend in net migration (field IX) were the hinterland of Munich and Freudenstadt. The strong economic and population growth of the Munich region and high housing costs in the core explain the rising popularity of the ring as a migrant destination. The trend for Freudenstadt has been strongly affected by the movements of ethnic Germans. While the patterns and trends in net migration for the total population are in line with those presented in the literature, these overall trends mask substantial variations in migration patterns in different age groups. Of key importance for regional population change are the mobile age groups of young adults and families, to which the paper now turns.

\subsection{Dynamics among $18-49$ year olds}

As shown in Section 4, the spatial patterns of migration among young and middleaged adults changed substantially over the last 16 years. The migration behaviour of these subgroups of the population is thus likely to have had a substantial impact on population change at the regional level. This Section looks more closely at the spatial patterns and temporal dynamics of migration among these three population groups and summarises the combined impact of their movements on the growth of core regions. The overall picture of migration among 18-24 year olds is one of strong net losses in almost all non-core regions, except for the hinterlands of Stuttgart and Munich (Fig. 11). The East-West divide in the degree of net-loss is not as 


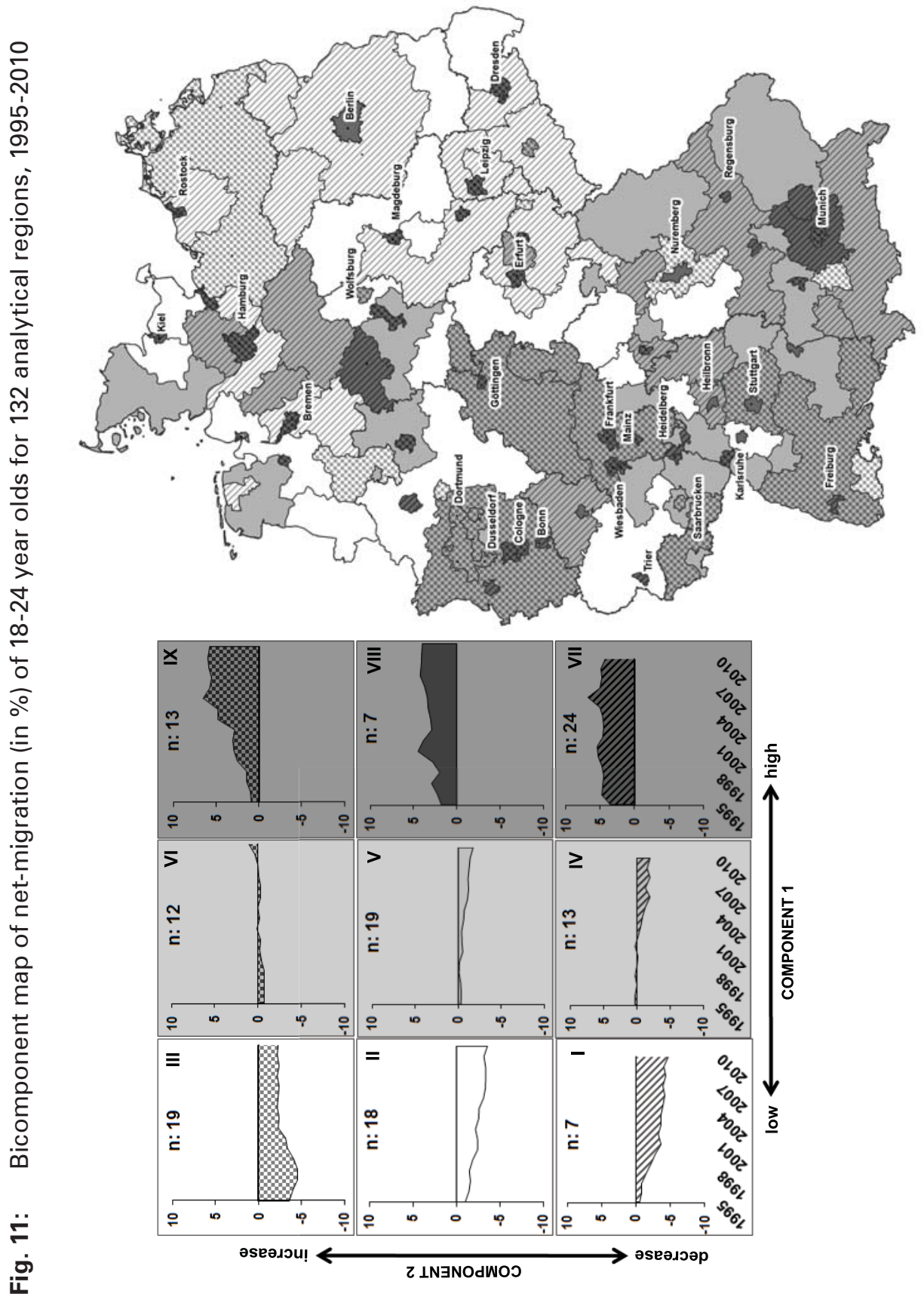

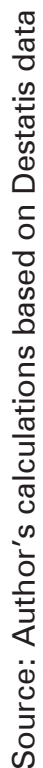


pronounced as for the total population discussed earlier. Several non-core regions in northern and southern Germany also experience out-migration among this highly mobile population group (fields I, II and III).

Compared to 18-24 year olds, the migration patterns among the population aged 25-29 show stronger and less systematic spatial variations in intensities and trends. This may be due to the variety of reasons for moving among this age group, which include education, job, marriage, family formation and altered housing needs. Each of these motivations is associated with different types of moves and destination choices. The mean net migration trends shown in Figure 12 highlight the increasing losses experienced by eastern German non-core regions, as well as by central and far-west regions (e.g. Saarbrücken County) (fields I, II and IV). At the other end of the spectrum, the trend for most core regions was positive, reflecting the general attractiveness of the cities for this age group (fields VI, VIII and IX). Noteworthy is the continuing net-gain in the hinterlands of Munich, Stuttgart, Frankfurt and Heidelberg-Mannheim (field VIII). All these regions have in common that they are located in commuting distance to agglomeration cores with expensive housing and strong labour markets.

The net migration behaviour of 30-49 year olds as shown in Figure 13 reveals several remarkable spatial patterns that may serve as a starting point for further research. The bicomponent map highlights decreasing outflows of 30-49 year olds to the cities' suburban and non-metropolitan hinterlands, as indicated by declining net losses in the core regions (fields II and III). This trend would have inevitably caused declining net gains in the cities' hinterlands. What is remarkable, however, is the far more universal pattern of declining net gains or even a change from gain to loss, which was experienced by all non-core regions, including the hinterland of Munich (fields IV, VII, VIII and IX). While regions in northern and southern Germany still gained families through migration at the end of the last decade, although at a lower rate (field IX), eastern and central German regions showed a pattern of beginning net loss. The regions with memberships of fields I, IV and V form a "belt-like" region that extends from Saarland in far-western Germany to Mecklenburg in the north-east. There seems to be a general trend of families breaking with the stereotype of the detached suburban family home and remaining in the core regions. The reasons related to behavioural changes have been discussed already in the literature (see, for example, Haase et al. 2010; Rérat 2011; West et al. 2008). The declining out-movement from the cores is especially important for the future population change in non-metropolitan regions. If the core-to-hinterland movement of families with small children continues to decrease, the children cannot become potential hinterland-to-core migrants once leaving the parental home. Given that, based on the current pattern, not all young adults move from non-core to core regions, the current family migration pattern might become a self-reinforcing trend where population is increasingly concentrated in core regions. 


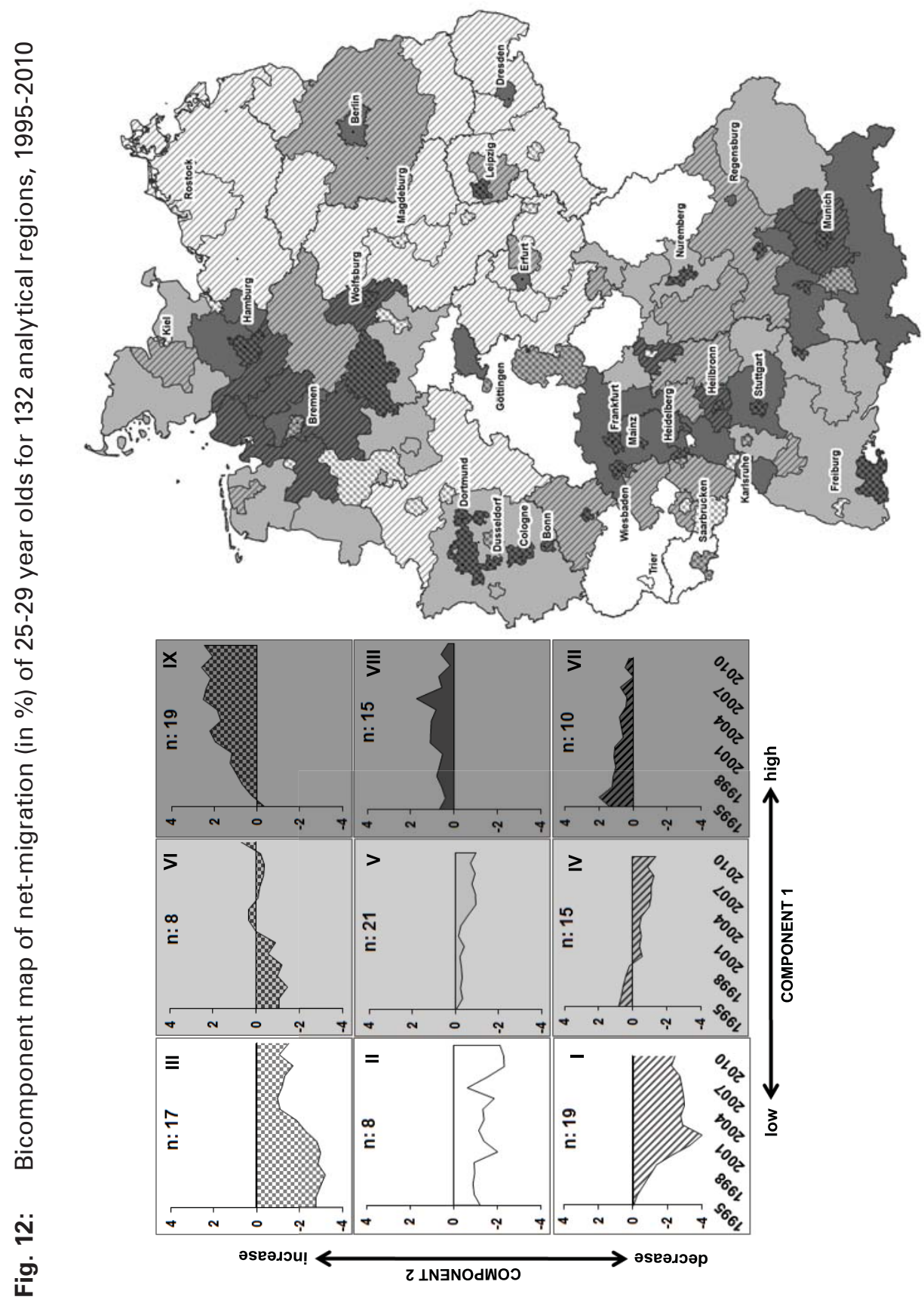

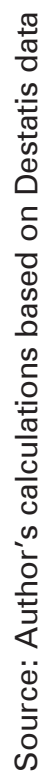




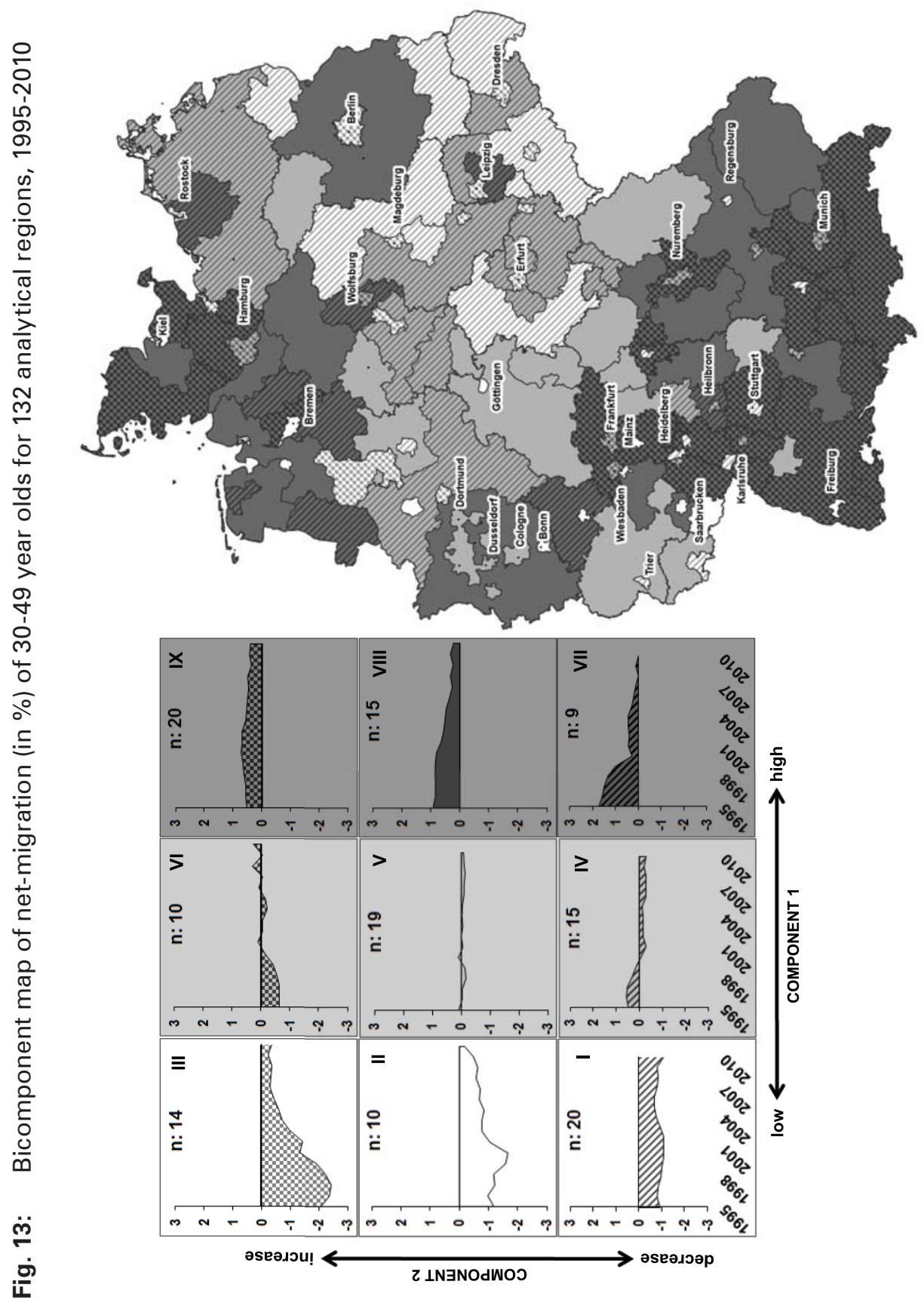

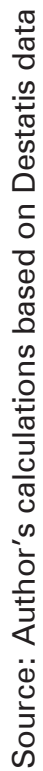




\subsection{In- and out-migration flows as drivers of urban growth}

The trend of increasing city growth and declining out-migration discussed in the previous Sections is likely to have been driven by two, at least in part, independent processes: stronger in-movement to cores among 18-24 year olds or less outmovement among 30-49 year olds. To shed light on what has been the driving force of urban growth, the effects of inflows and outflows on net migration need to be disentangled. The bicomponent maps showing in-migration of young adults aged 18-24 (Fig. 14) and out-migration of 30-49 year olds (Fig. 15) suggest that both processes have contributed to the growth of core regions. The overall pattern is one of increasing in-migration to the urban cores among young adults, paralleled by decreasing out-migration from the cores among 30-49 year olds. But this overall trend disguises substantial differences between agglomeration cores. In 2010, Heidelberg and Darmstadt recorded the highest in-migration rates among young adults $(22.8$ percent and 20.6 percent respectively), but also the highest out-migration rates among families (6.9 percent and 6.5 percent respectively). In contrast, the cities of Essen and Wuppertal experienced very low levels of both in-migration (6.9 percent and 6.6 percent respectively) and out-migration (2.8 percent and 3.4 percent respectively). A very different pattern of growth was recorded by the cities of Dresden and Leipzig, where the in-migration rate of 18-24 year olds was with 16.5 percent relatively high, but out-migration of 30-49 year olds was much below average (3.4 percent in both cities).

A closer look at the changes over time in the core regions reveals three different combinations of in- and out-migration trends that have driven overall growth. A first group of agglomeration and urban core regions (Cologne, Frankfurt, Munich, Stuttgart and all eastern cores) recorded increasing in-migration of 18-24 year olds (fields VI and IX), while family out-movement remained relatively stable (fields II, VI and IX). The second group of urban cores (Aschaffenburg, Freiburg, Heilbronn and Münster) were characterised by stable in-movements (field VII) and declining outmovements (field VII). Bremen and Nuremberg formed the third group, which recorded both increasing in-migration of young adults (field IX) and less out-migration of families (field VIII).

In terms of impact on regional population change, the third group may be the most significant, although the self-reinforcing pattern of decreasing family outmigration discussed earlier may also impact strongly on future growth. However, any speculations about future changes in population size and age structure need to consider the regions of origin of young adults moving to the cores, as well as the destinations of families moving in the opposite direction. This question is important because it determines the degree of redistribution of population through migration. For example, population is redistributed if young adults move from the hinterland of region $A$ to its core, while families who move out of core $A$ move to the hinterland of region $B$. Otherwise, if these families move back to the hinterland of region $A$, such an hypothetical setting would lead to an exchange of population between a core and its hinterland. 
Internal Migration in Germany, 1995-2010 239

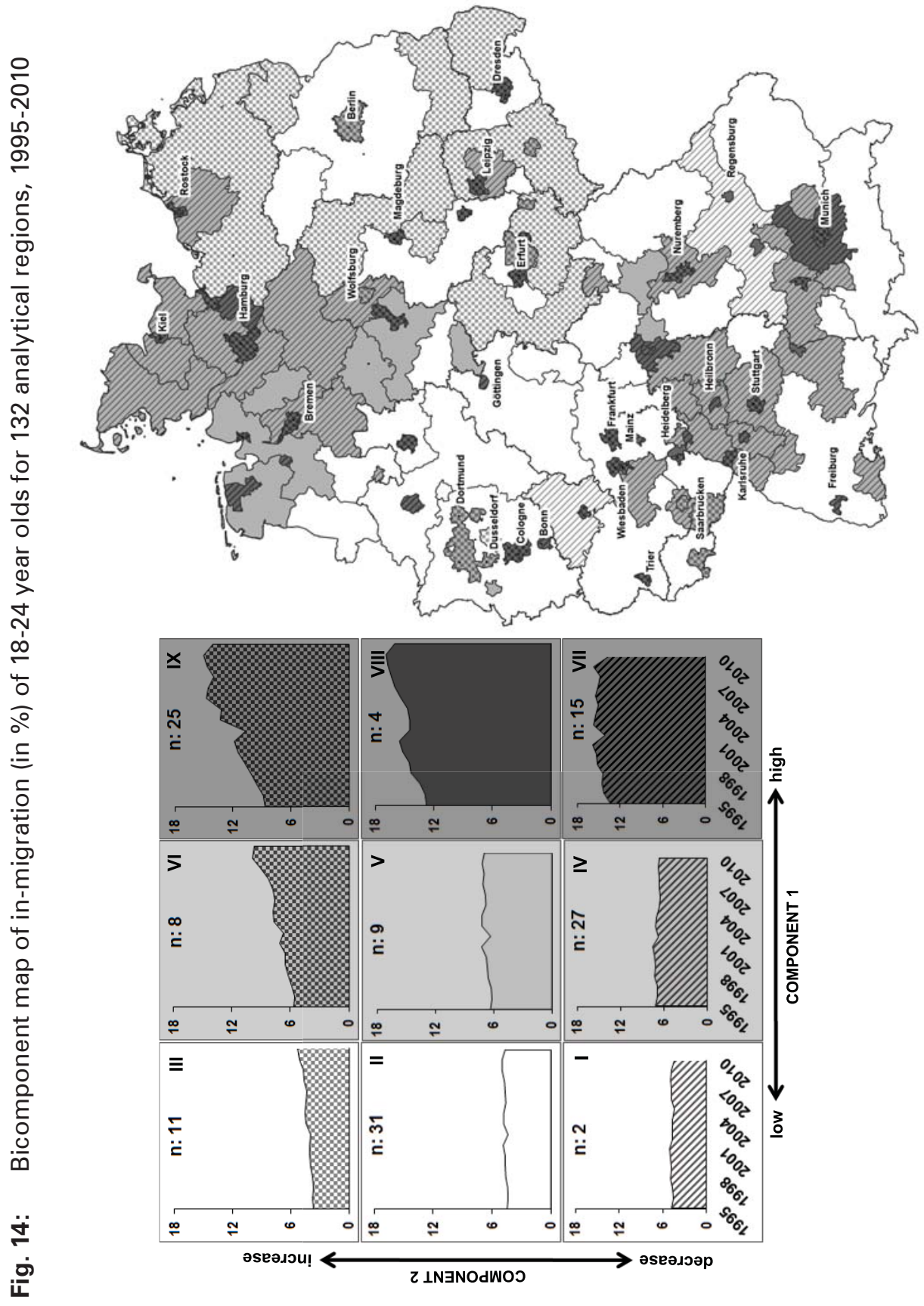

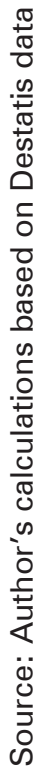




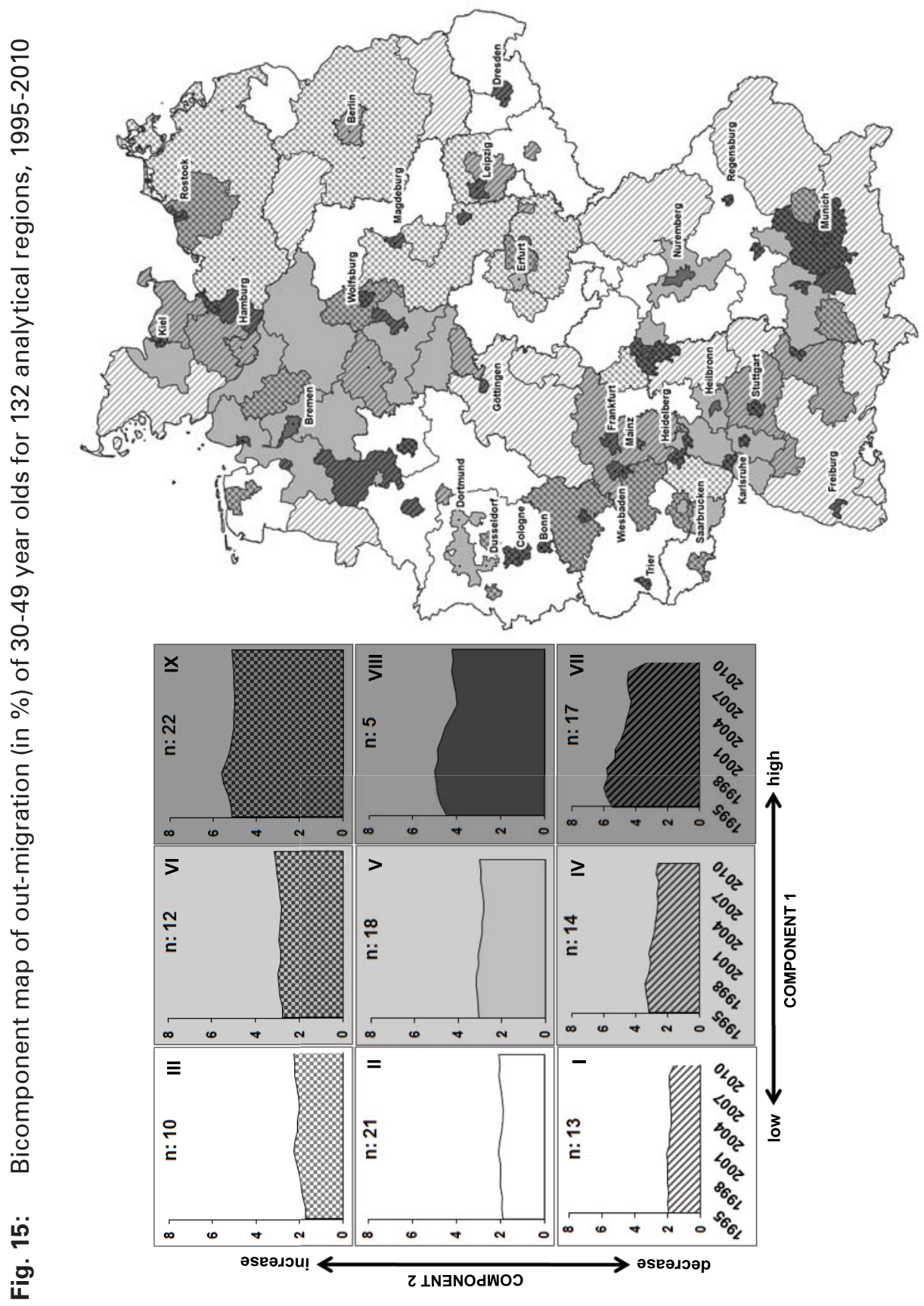

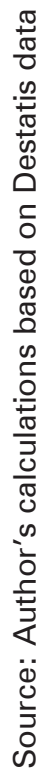




\section{Origins and destinations of flows to and from large cities}

In order to compare the origins of in-migrants to the largest German agglomeration cores with the destinations of its out-migrants, the numbers of in-migrants to and out-migrants from six selected cities were compared across cities and over time using the spatial framework discussed in Section 3. The numbers of migrants for each of the seven region types were translated into shares of the total in- and out-flows in order to avoid problems of scale in interpreting the trends. A distinction was made between the target city's own hinterland and all other regions in order to address the issue of redistribution versus exchange that was introduced earlier.

The shares by region type shown in Figure 16 highlight remarkable differences in the composition of in-migration and out-migration flows between the six German cities and point to a clear trend of migration up the urban hierarchy. The shares of migrants from non-metropolitan areas to the selected cities were larger than the corresponding shares in the outflow to non-metropolitan areas. Moreover, cities drew in a considerable share of their migrants from outside their own hinterland, but sent a much larger share to their own hinterland. It should be noted, however, that the city-hinterland relationships are partly determined by the size of a city's own hinterland and the distance to other types of regions. For example, the city of Leipzig is located in closer proximity to other non-metro areas and urban rings than the city of Berlin. The proximity might explain why Leipzig recorded a higher share of in-migrants from these region types than Berlin. Similarly, Frankfurt sends a higher share of out-migrants to other agglomeration cores, because the cities of Mainz and Wiesbaden are located in close proximity, and Munich received a larger share of in-migrants from the relatively closely located non-metro alpine region.

A comparison of the patterns over time shows that the city-hinterland relationships were broadly consistent. This finding suggests that the recent renaissance of the city has been universally observed across all types of origin regions of young adults as well as all traditional destinations of young families leaving the cities. The trend of migration up the urban hierarchy somewhat intensified from 1995 to 2010, with an increasing share of out-migrants moving to other agglomeration cores and fewer migrants moving to the cities' own hinterlands. The differences across cities in the shares sent to their own hinterland may in part be explained by the competition for and the affordability of housing. The cities of Frankfurt, Stuttgart, Munich and Hamburg are all characterised by tighter and more expensive housing markets compared to Berlin and Leipzig. Consequently, a larger share of families still chose to move out of the city into the hinterland regions where competition on the housing market is less strong.

The most substantial changes over time were observed for the composition of out-migration from the city of Leipzig. While in both years in-migrants were almost evenly distributed across the seven region types and the city's own hinterland, outmigration to the city's hinterland decreased strongly over time. In 2010, Leipzig's share of out-migrants moving to other agglomeration cores, presumably Berlin and Dresden, was almost as large as the share it sent to its own hinterland. Therefore, Leipzig redistributes population through migration in a crucially different way than 
Fig. 16: Composition of inflows among 18-24 year olds and outflows among 3049 year olds to and from large German cities in 1995 and 2010

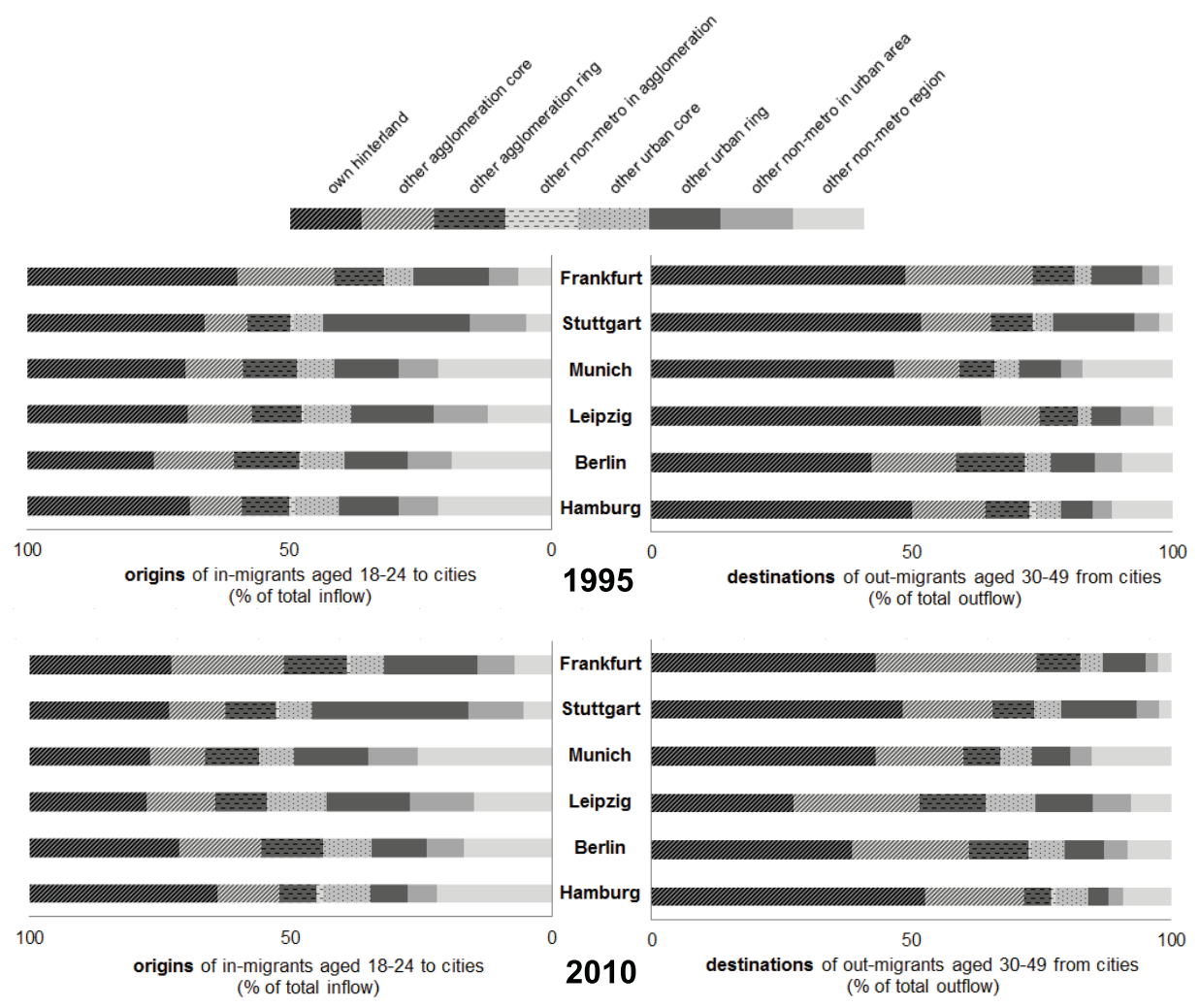

Source: Author's calculations based on Destatis data

the other five cities. The relatively affordable housing stock and the lower attractiveness of the local labour market compared to the other five cities may go some way toward explaining the decreasing out-migration to the hinterland.

\section{Conclusions}

This paper provided a more comprehensive picture of the spatial structure of interregional migration in Germany and highlighted substantial dynamics over the period 1995-2010. Although numerous recent articles have focused on East-West migration and reurbanisation, the literature is characterised by micro-level studies and by descriptive work, mostly focusing on net-migration, state-level patterns, or exclusively on migration streams between eastern and western states. Hence, an argument was made that the debate about internal migration and its impact on regional population change requires a better understanding of the intensities and spatial patterns of migration. By drawing on data from the newly developed German 
Internal Migration (GIM) database, the analysis presented here could overcome the limitations imposed by changes in boundaries of administrative regions that have thus far hindered comparisons of internal migration over time.

Since 1995, the overall intensity of internal migration between Germany's regions showed only minor changes over time, whereas larger discrepancies were apparent for migration between eastern German regions and the core-hinterland relationship. The results highlight the importance of movements from East German cities to suburban hinterlands for regional population change in the late 1990s. The intensity of such moves between the eastern counties was substantially higher than the much debated East-West migration and showed marked changes over time. Changes in the core-hinterland relationship were driven by the combined effects of (a) a decline in net out-migration from the cores to their hinterlands among families, commonly referred to as suburbanisation, and (b) an increase in net in-migration from both hinterlands and other non-metropolitan regions among younger adults. The onset of both changes was relatively slow and resulted in a gradual increase of urban populations, and a remarkably universal pattern of decreasing net gains or even changes from gain to loss in the cities' hinterlands and non-metropolitan regions. The spatial variation in the intensity of the change in the cores, however, was much more pronounced. While the changes in the cities of Frankfurt, Munich, Stuttgart, Leipzig and Berlin were driven by increasing in-migration, it was higher out-migration that triggered population growth in Freiburg, Heilbronn and Münster. The growth of populations in Bremen and Nuremberg was driven by both factors.

The underlying causes of the core's population growth have been discussed extensively since first signs of this trend became apparent in the late 1980s. In the German case, declining family size, women's increasing labour force participation, the growing dependence of families on child care facilities, increasing costs of commuting, and new-build residential development may go some way in explaining the growing attractiveness of the core regions as a place to live. This paper has shown, however, that the processes and patterns underlying the renewed urban growth differ substantially between cities, even between those within the same state. In the context of growing urban concentration of population, such spatial variation points to a shift from competition between city cores and their hinterlands to competition between the cities, a trend which in times of globalisation may well extend to the European level.

\section{Acknowledgements}

I thank Ramon Bauer and two anonymous referees for their helpful comments and suggestions. 


\section{References}

Blake, Marcus; Bell, Martin; Rees, Phil 2000: Creating a Temporally Consistent Spatial Framework for the Analysis of Interregional Migration in Australia. In: International Journal of Population Geography 6,2: 155-174 [doi: 10.1002/(SICI)10991220(200003/04)6:2<155::AID-IJPG180>3.0.CO;2-A].

Boyle, Paul 1995: Rural in-migration in England and Wales 1980-1981. In: Journal of Rural Studies 11,1: 65-78.

BBSR (Bundesinstitut für Bau-, Stadt- und Raumforschung) 2009: Siedlungsstrukturelle Kreistypen, Stand 2009, Bonn [http://www.bbsr.bund.de/cln_032/nn_340582/BBSR/ $\mathrm{DE} /$ Raumbeobachtung/Raumabgrenzungen/SiedlungsstruktürelleGēietstypen/Kreistypen/Downloadangebote, 26.02.2013].

Buzar, Stefan et al. 2007: Splintering urban populations: emergent landscapes of reurbanisation in four European cities. In: Urban Studies 44: 651-677 [doi: 10.1080/00420980601185544].

Colomb, Claire 2007: Unpacking New Labour's 'renaissance agenda': towards a socially sustainable reurbanisation of British cities? In: Planning Practice and Research 22: 1-24 [doi: 10.1080/02697450701455249].

Flowerdew, Robin; Lovett, Andrew 1988: Fitting Constrained Poisson Regression Models to Interurban Migration Flows. In: Geographical Analysis 20: 297-307.

Gatzweiler, Hans-Peter; Sch/ömer, Claus 2008: Zur Bedeutung von Wanderungen für die Raum- und Stadtentwicklung. In: Informationen zur Raumentwicklung 3,4: 245-259.

Haase, Annegret et al. 2010: Emergent spaces of reurbanisation: exploring the demographic dimension of inner-city residential change in a European setting. In: Population, Space and Place 16,5: 443-463 [doi: 10.1002/psp.603].

Heiland, Frank 2004: Trends in East-West German migration from 1989 to 2002. In: Demographic Research 11,7: 173-194.

Hesse, Markus 2008: Reurbanisierung? Urbane Diskurse, Deutungskonkurrenzen, konzeptuelle Konfusion. In: Raumforschung und Raumordnung 66: 415-428 [doi: 10.1007/ BF03183185].

Kabisch, Nadja; Haase, Dagmar; Haase, Annegret 2010: Evolving reurbanisation? Spatio-temporal dynamics as exemplified by the east German city of Leipzig. In: Urban Studies 47,5: 967-990 [doi: 10.1177/0042098009353072].

Kemper, Franz-Josef 2008: Residential mobility in East and West Germany: mobility rates, mobility reasons, reurbanization. In: Zeitschrift für Bevölkerungswissenschaft 33,3-4: 293-314 [doi: 10.1007/s12523-009-0018-1].

Kontuly, Thomas; Vogelsang, Roland; Schön, Karl P.; Maretzke, Steffen 1997: Political unification and regional consequences of German east-west migration. In: International Journal of Population Geography 3,1: 31-47.

Köppen, Berhard 2008: Reurbanisierung als Hoffnung der Städte im demographischen Wandel? In: Maretzke, Steffen (Ed.): Städte im demografischen Wandel. Wesentliche Strukturen und Trends des demografischen Wandels in den Städten Deutschlands. Wiesbaden: Materialien zur Bevölkerungswissenschaft, Bd. 125: 31-40.

Kröhnert, Steffen; Vollmer, Sebastian 2012: Gender-Specific Migration from Eastern to Western Germany: Where Have All the Young Women Gone? In: International Migration 50,5: 95-112 [doi: 10.1111/j.1468-2435.2012.00750.x].

Lee, Everett S. 1966: A theory of migration. In: Demography 3,1: 47-57. 
Lever, William F. 1993: Reurbanisation: the policy implications. In: Urban Studies 30: 267-284 [doi: 10.1080/00420989320080281].

Openshaw, Stan 1984: The Modifiable Areal Unit Problem. Norwich: GeoBooks.

Peukert, Christian; Werner Smolny 2011: Interregional Migration in Germany: Characteristics and Effects for Regions and Migrants, Discussion Paper [http://ssrn.com/abstract $=1782013]$

Rérat, Patrick 2011: The new demographic growth of cities. The case of reurbanization in Switzerland. In: Urban Studies [doi: 10.1177/0042098011408935].

Rink, Dieter et al. 2012: From Long-Term Shrinkage to Re-Growth? The Urban Development Trajectories of Liverpool and Leipzig. In: Built Environment 38,2: 162-178 [doi: http://dx.doi.org/10.2148/benv.38.2.162].

Rogers, Andrei; Little, Jani; Raymer, James 2010: The indirect estimation of migration: Methods for dealing with irregular, inadequate, and missing data. Springer: Dordrecht.

Rogers, Andrei; Raquillet, Richard; Castro, Luis J. 1978: Model migration schedules and their applications. In: Environment and Planning A, 10, 5: 475-502.

Schlömer, Claus 2009: Binnenwanderung in Deutschland zwischen Konsolidierung und neuen Paradigmen, Band 31. BBSR, Bonn.

Sch/ömer, Claus 2012: Zusammenhänge zwischen internationalen Wanderungen und Binnenwanderungen - die indirekten Folgen der Internationalisierung. In: Köppen, Bernhard et al. (Eds.): Internationalisierung. Die unterschätzte Komponente des demographischen Wandels in Deutschland?. Schriftenreihe der DGD, Bd. 5, Norderstedt: 43-64.

Schroeder, Jonathan P. 2009: Visualizing patterns in U.S. Urban population trends. Unpublished PhD Thesis, University of Minnesota [http://purl.umn.edu/48076, 26.02.2013]

Siedentop, Stefan 2008: Die Rückkehr der Städte? Zur Plausibilität der Reurbanisierungshypothese. In: Informationen zur Raumentwicklung 3,4: 193-210.

Schuhoff, Kristina; Hußing, Ulrich 2008: Regionale Unterschiede im demografischen Wandel zwischen Hamburg und Flensburg. In: Sozialwissenschaft und Berufspraxis 31,2: 302-315.

Stillwell, John; Hussain, Serena; Norman, Paul 2008: The internal migration propensities and net migration patterns of ethnic groups in Britain. In: Migration Letters 5,2: 135-150.

West, Cristina; Gans, Paul; Schmitz-Veltin, Ansgar 2008: Cities in space and city as place - Rethinking reurbanisation: urban, semi-urban and suburban orientations and their impact on the choice of residence. In: Zeitschrift für Bevölkerungswissenschaft 33: 3-4: 381-408 [doi: 10.1007/s12523-009-0021-6].

Date of submission: 07.10 .2012

Date of acceptance: 25.03 .2013

Dr. Nikola Sander $(\varangle)$. Wittgenstein Centre for Demography and Global Human Capital (a collaboration of IIASA, VID/ÖAW, WU), Vienna Institute of Demography of the Austrian Academy of Sciences. Vienna, Austria. E-Mail: nikola.sander@oeaw.ac.at,

URL: http://www.oeaw.ac.at/vid/staff/staff_nikola_sander.shtml 


\section{Comparative Population Studies}

WWW.comparativepopulationstudies.de

ISSN: 1869-8980 (Print) - 1869-8999 (Internet)

Published by / Herausgegeben von

Prof. Dr. Norbert F. Schneider

Federal Institute for Population Research

D-65180 Wiesbaden / Germany

Managing Editor /

Verantwortlicher Redakteur

Frank Swiaczny

Assistant Managing Editor /

Stellvertretende Redakteurin

Katrin Schiefer

Language \& Copy Editor (English) /

Lektorat \& Übersetzungen (englisch)

Amelie Franke

Copy Editor (German) /

Lektorat (deutsch)

Dr. Evelyn Grünheid

\section{Layout / Satz}

Beatriz Feiler-Fuchs

E-mail:cpos@bib.bund.de

\author{
Scientific Advisory Board / \\ Wissenschaftlicher Beirat \\ Paul Gans (Mannheim) \\ Johannes Huinink (Bremen) \\ Michaela Kreyenfeld (Rostock) \\ Marc Luy (Wien) \\ Clara H. Mulder (Groningen) \\ Notburga Ott (Bochum) \\ Peter Preisendörfer (Mainz) \\ Zsolt Spéder (Budapest)
}

\section{Board of Reviewers / Gutachterbeirat} Martin Abraham (Erlangen)

Laura Bernardi (Lausanne)

Hansjörg Bucher (Bonn)

Claudia Diehl (Konstanz)

Andreas Diekmann (Zürich)

Gabriele Doblhammer-Reiter (Rostock)

E.-Jürgen Flöthmann (Bielefeld)

Alexia Fürnkranz-Prskawetz (Wien)

Beat Fux (Salzburg)

Joshua Goldstein (Berkeley)

Karsten Hank (Köln)

Sonja Haug (Regensburg)

Aart C. Liefbroer (Den Haag)

Kurt Lüscher (Konstanz)

Dimiter Philipov (Wien)

Tomáš Sobotka (Wien)

Heike Trappe (Rostock) 